\title{
QUALITATIVE ANALYSIS OF INORGANIC ACID, BASIC RADICALS, AND ESTIMATION OF BIOMOLECULES IN THE FLOWER EXTRACT OF BUTEA SUPERBA ROXB.
}

\author{
SEETHALAKSHMI B ${ }^{1 *}$, KAVITHA ${ }^{2}$ \\ ${ }^{1}$ Assistant Professor, Department of Humanities and Science, Mugavari Eye Hospital and Research Institute, Medavakkam, \\ Chennai - 600 100, Tamil Nadu, India. ${ }^{2}$ Research Scholar, Department of Zoology, Guru Nanak College, Velachery, Chennai - 600042 , Tamil \\ Nadu, India. Email: lakshmiseetha895@gmail.com \\ Received: 03 May 2018, Revised and Accepted: 12 June 2018
}

ABSTRACT

Objective: Medicinal plants have different chemicals in their roots, stem, leaves, flowers, and fruits. In human history, medicinal plants play a vital role in the traditional medicine because of herbal plants have a great nutritive value, and some of them are also used in medicine. The efficacy of medicinal plants is mainly allied with their components such as secondary metabolites and inorganic acid, and basic radicals considered that prolonged intake can cause health problems if the heavy metals such as mercury, cadmium, and other impurities are the threshold concentrations.

Methods: In the present study, the flower extract of Butea superba was analyzed for the inorganic acid and basic radicals and the estimation of total saponins, terpenoids, and alkaloids. The above protocols were done using standard methods.

Results: The flower extract of B. superba revealed that the inorganic acid radicals such as chromate, phosphate, and sulfate and the basic radicals such as lead, arsenic, and ferrous showed that positive results. The percentage of total saponins, terpenoids, and alkaloids were compared in the following order, saponins $<$ terpenoids $<$ alkaloids as $4.181 \pm 0.017 \%<79.833 \pm 0.351 \%<107.823 \pm 0.105 \%$, respectively.

Conclusion: The present study revealed that the inorganic acid and basic elements of B. superba flower extract. The estimation of secondary metabolites such as total saponins, terpenoids, and alkaloids proved that the flower extract of B. superba is used to treat many diseases.

Keywords: Butea superba, Acid radicals, Phytochemicals, Red Kwao Krua.

(C) 2018 The Authors. Published by Innovare Academic Sciences Pvt Ltd. This is an open access article under the CC BY license (http://creativecommons. org/licenses/by/4. 0/) DOI: http://dx.doi.org/10.22159/ajpcr.2018.v11i10.27087

\section{INTRODUCTION}

Nature has been the biggest storehouse of medicinal agents for 1000 of years, and a majestic number of synthetic drugs have been isolated from natural resources, many of which is based on their use in traditional medicine [1]. Medicinal plants include different types of plants used in herbalism, and some of these plants have medicinal values and considered as a rich source of organic compounds and used for traditional medicinal system of drugs, food supplements, nutraceuticals, and medicines of modern era, folk medicines, pharmaceuticals, intermediates, and chemicals used for synthetic drugs [2]. Besides that herbal plants play an important role in the progress of human cultures in worldwide [3].

Ancient people depend on herbal plant extracts for the remedial source of many diseases [4]. Medicinal plants play a vital role in the primary health care of traditional medicinal systems. The major merits of herbal medicines are their potential, easy availability, less expensive, and ecofriendly and have lesser side effects [5]. In India, almost 95\% of the prescriptions have been reported to be plant based in the traditional systems of Unani, Ayurveda, Homeopathy, and Siddha [6,7]. In ancient time, Ayurveda is considering as one of the traditional Indian medicinal practices which use medicinal plants as curative agent [8].

The plant parts also contain both organic and inorganic substances. Nutritional and mineral components are consider as important factor to determine the quality of herbs. Inorganic compounds play a dynamic role against a variety of degenerative diseases. Inorganic constituents such as phosphorous, potassium, iron, zinc, calcium, and sodium are essential to lead a healthy life [9-11].

The trace amounts of inorganic compounds are essential into play an important role in nutrition, enzyme reaction and also in the metabolic processes [12]. Metals and trace elements have a key role to play in the pathophysiology of human diseases [13]. In biological system, metals and minerals play an important role in the metabolism [14].

Medicinal plants produce primary and secondary metabolites with different functions [15]. The secondary metabolites which include organic substances such as alkaloids, terpenoids, and phenolic compounds are known to be responsible for the therapeutic potential of the herbal plants [16]. Herbal plants can produce different kind of secondary metabolites also known as natural products as they provoke effects on other organisms [17]. The most important phytochemicals are saponins, flavonoids, alkaloids, phenolic groups, tannins, and terpenoids [18].

Saponin is one of the chemical compounds in the class of amphipathic glycosides due to formation of soap-like foam in aqueous solution [19]. The word saponin was derived from the plant "soapwort" and its roots were used for foaming. Most of these compounds have detergent properties and give the foams in water. It has colloidal solution form in water and if the mixture is shaken, it form foamy like soap [20]. Saponin can be found on the roots and leaves of plants [21]. Saponin compounds which are present in medicinal plants have profitable effects. Among the different biological effects of saponins are antibacterial and antiprotozoal [22-24] and anticancer activities [25].

Saponin has association with sex hormone-like oxytocin. Oxytocin is a sex hormone involved into control the onset of labor in women and the succeeding release of milk [26]. Saponins are also used in veterinary industry. Some of the saponins act as adjuvant and it can be added to vaccines (e.g. foot-and-mouth disease vaccines) and help to improve immune response.

Terpenoids are the group of compounds, predominantly which occur in the plant kingdom, and few terpenoids have been obtained from other 
sources. These terpenoid compounds are effectively used in disease therapy and prevention of many human diseases. Terpenoid compounds have been used to treat inflammation, malaria, cancer, and a variety of infectious disease which is caused by bacteria and virus [27]

Alkaloids are distinct group of nitrogen-containing, low-molecularweight compounds which occur in plant kingdom. Approximately 12,000 different types of alkaloids have been well known to occur in all plants as well as more than 150 families, such as Fabaceae, Papaveraceae, Apocynaceae, Rubiaceae, and Solanaceae. Alkaloids are accumulating huge amounts in specific parts of plants such as roots, stem barks, and seeds [28]. Alkaloids have many biological activities. The alkaloids and their derivatives are used as antispasmodic, analgesic, and antibactericidal drugs [29]. Morphine, quinine, ephedrine, nicotine, and strychnine are consider as major type of alkaloids, and some of these are used in narcotic analgesics as well as anti-tissue agents [30,31].

Butea superba Roxb. is a plant in the family Fabaceae and commonly known as "Red Kwao Krua" [32] in Tamil it is known as Kodimurukkan. The flowers are yellowish orange color, about $4-5 \mathrm{~cm}$ in length that blossom when the plant sheds its leaves. B. superba was traditionally reported to possess antioxidant activities, aphrodisiac, estrogenic, and antibacterial properties. Hence, the present study was undertaken for the analysis of inorganic acid, basic radicals, and estimation of total saponins in the flower extract of $B$. superba.

\section{MATERIALS AND METHODS}

\section{Collection site of plant materials}

The dried flower samples were purchased from the Herbal Health Research Consortium Pvt., Ltd., Amritsar, India.

\section{Authentication}

The flowers of B. superba (Family: Papilionaceae (Fabaceae) were authenticated by Dr. P. Jayaraman, Botanist, Plant Anatomy Research Centre, Chennai. The specimen no is PARC/2016/3280.

\begin{tabular}{llll}
\multicolumn{3}{l}{ Scientific classification of B. superba Roxb. } \\
Kingdom $:$ & Plantae \\
Division $:$ & Magnoliophyta \\
Class $\quad:$ & Magnoliopsida \\
Order $\quad:$ & Fabales \\
Family $\quad:$ & Fabaceae \\
Genus $\quad:$ & Butea \\
Species $\quad:$ & Superba \\
Common name & $:$ & Red Kwao Krua \\
Tamil name & $:$ & Kodimurukkan.
\end{tabular}

\section{Preparation of plant extract}

The dried flowers were brought to the laboratory and kept at room temperature $\left(30^{\circ} \mathrm{C} \pm 2^{\circ} \mathrm{C}\right)$ under aseptic condition to prevent microbial contamination. After that, the flowers were ground into powder form using a mixer grinder. The powder was kept in the airtight polythene bags and stored at dry place (Fig. 1).

The plant extract was prepared using a standard method followed by [33,34]. $1 \mathrm{~g}$ of the powder was taken and mixed with $20 \mathrm{ml}$ of acetone using an ULTRA-TURAX mixer (13,000 rpm) and left overnight at room temperature. The sample was then filtered using Whatman no.1 paper in a Buchner funnel. The filtered solution was evaporated under vacuum in a rotary evaporator at $40^{\circ} \mathrm{C}$. The obtained concentrated extract was dissolved in respective solvent and stored in airtight centrifugal tube separately in a refrigerator at $5^{\circ} \mathrm{C} \pm 1^{\circ} \mathrm{C}$

\section{Qualitative analysis of mineral content in the flower extract of} B. superba

The mineral content of $B$. superba flower extract was analyzed using the standard methods [35].

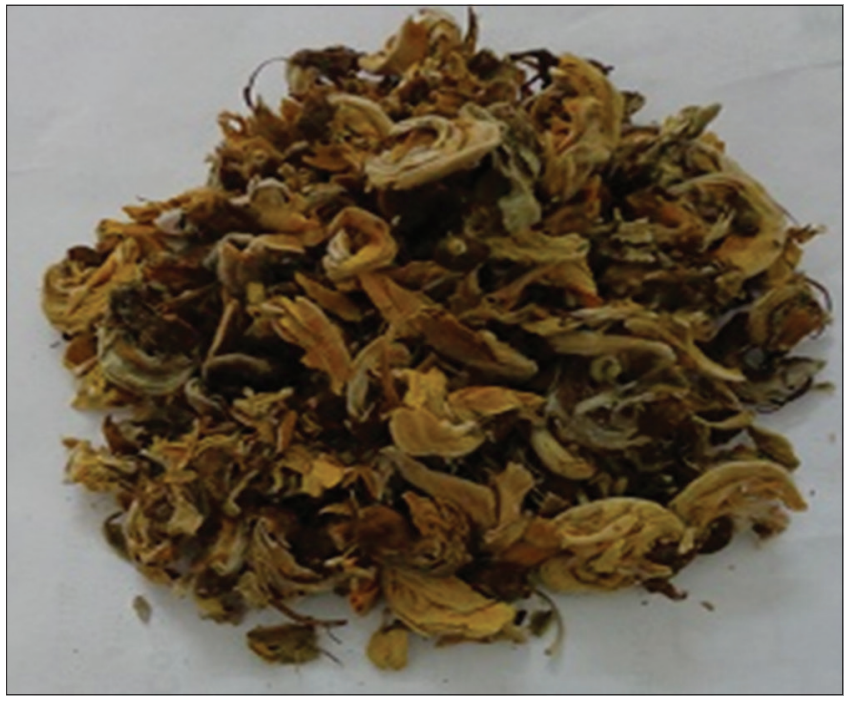

Fig. 1: Dried flower of Butea superba

\section{Analysis of inorganic acid radicals}

Test for carbonates

$1 \mathrm{ml}$ of the plant extract was taken in a clean dry test tube, and $1 \mathrm{ml}$ of concentration (conc.) HCL was added. Formation of brisk effervescence indicated the presence of carbohydrates.

\section{Test for chlorides}

$1 \mathrm{ml}$ of flower extract was taken in a clean test tube, and $1 \mathrm{ml}$ of silver nitrate solution was added. White precipitate was formed indicated the presence of chlorides.

\section{Test for chromates}

Heat $0.1 \mathrm{~g}$ of the substance with sodium chloride and $0.3 \mathrm{~g}$ of potassium dichromate and $1 \mathrm{ml}$ of sulfuric acid $\left(\mathrm{H}_{2} \mathrm{SO}_{4}\right)$ taken in the dry test tube. Pass the red vapor of chromyl chloride into water. Add $1 \mathrm{ml}$ ammonium hydroxide $\left(\mathrm{NH}_{4} \mathrm{OH}\right)$ and $1 \mathrm{ml}$ acetic acid and $1 \mathrm{ml}$ lead acetate. Formation of yellow precipitate indicated the presence of chromates.

\section{Test for nitrates (brown ring test)}

$1 \mathrm{ml}$ of the sample was taken in a clean and dry test tube and added diluted $\mathrm{H}_{2} \mathrm{SO}_{4}$ till there is no effervescence. Add ferrous sulfate along the sides of the test tube. Brown ring was formed at the junction of two liquids indicated nitrates.

\section{Test for phosphates (ammonium molybdate test)}

$1 \mathrm{ml}$ of the extract was taken in a test tube add $2 \mathrm{ml}$ of conc. Nitric acid $\left(\mathrm{HNO}_{3}\right)$ and warmed. This mixture was cooled under the tap water. After that, $5 \mathrm{ml}$ of ammonium molybdate solution was added in the test tube. Formation of yellow precipitate indicated the presence of phosphates.

\section{Test for sulfates}

$1 \mathrm{ml}$ of the sample was taken in a test tube with diluted $\mathrm{H}_{2} \mathrm{SO}_{4}$ till there is no effervescence after that added $1 \mathrm{ml}$ of barium chloride solution. Appearance of white precipitate was regarded as sulfates.

\section{Test for sulfides}

$1 \mathrm{ml}$ of the sample was taken in a test tube and added $2 \mathrm{ml}$ of diluted HCL and warms this mixture. Formation of colorless gas with the smell of rotten egg indicated the presence of sulfides. 


\section{Analysis of inorganic basic radicals}

Test for lead

$1 \mathrm{ml}$ of the flower extract was taken in a test tube and added $2 \mathrm{ml}$ of potassium chromate solution. Formation of yellow precipitate indicated the presence of lead.

\section{Test for arsenic}

$3 \mathrm{ml}$ of the flower extract was taken and add $2 \mathrm{ml}$ of $10 \%(2 \mathrm{~N})$ sodium hydroxide $(\mathrm{NaOH})$ solution. Formation of brownish red precipitate indicated the presence of phosphates.

\section{Test for mercury}

$3 \mathrm{ml}$ of the flower extract was taken and add $2 \mathrm{ml}$ of $10 \%$ (2N) $\mathrm{NaOH}$ solution. Appearance of yellow precipitate indicated the presence of mercury.

\section{Test for copper}

$1 \mathrm{ml}$ of the flower extract was taken in a test tube and added $1 \mathrm{ml}$ of $\mathrm{NH}_{4} \mathrm{OH}$ solution. Then, light blue precipitate appears. Add excess $\mathrm{NH}_{4} \mathrm{OH}$.

Initially, light blue precipitate formed after that it will become dark blue.

\section{Test for ferric}

$2 \mathrm{ml}$ of potassium ferrocyanide was taken in a test tube and add $1 \mathrm{ml}$ of the flower extract. Formation of blue precipitate showed the presence of ferric.

\section{Test for ferrous}

$2 \mathrm{ml}$ of potassium ferric cyanide was taken in a test tube and add $1 \mathrm{ml}$ of the flower extract. Appearance of blue precipitate indicated the presence of ferrous.

\section{Test for zinc}

$1 \mathrm{ml}$ of the flower extract was taken in a test tube and added $1 \mathrm{ml}$ of $\mathrm{NaOH}$ solution. White precipitate was observed indicated the presence of zinc.

\section{Test for silver}

$1 \mathrm{ml}$ of the flower extract was taken in a test tube and added $1 \mathrm{ml}$ of conc. HCL after that curdy white precipitate appeared. Boil the precipitate with water. It does not dissolve. Add $\mathrm{NH}_{4} \mathrm{OH}$ solution in it and add $1 \mathrm{ml}$ dilute $\mathrm{HNO}_{3}$. Formation of curdy white precipitate indicated the presence of silver.

\section{Estimation of total saponins}

The estimation of total saponins was done by [36] slight modification. $1 \mathrm{~g}$ of the powdered flower sample was weighed and it was dispersed in $100 \mathrm{ml}$ of $20 \%$ ethanol. The suspension was heated over a water bath for $4 \mathrm{~h}$ with continuous stirring at about $55^{\circ} \mathrm{C}$. The filtrate and the residue were re-extracted with another $100 \mathrm{ml}$ of $20 \%$ ethanol. The combined extracts were reduced to $40 \%$ over water bath at about $90^{\circ} \mathrm{C}$. The concentrate was transferred into separator funnel, and $20 \mathrm{ml}$ diethyl ether was added and shaken vigorously then extracted twice with $20 \mathrm{ml}$ diethyl ether. The aqueous layer was recovered while the ether layer was discarded. The purification process was repeated and about $30 \mathrm{ml}$ n-butanol was added. The n-butanol extracts were washed twice with $10 \mathrm{ml}$ of $5 \%$ aqueous sodium chloride. The remaining solution was heated in a water bath. After evaporation, the samples were dried in the oven at $40^{\circ} \mathrm{C}$ to a constant weight. The saponin content was calculated using the following formula:

Calculation

Total saponin content $(\%)=(\mathrm{FW} / \mathrm{IW}) \times 100$
Where,

FW=Final weight of sample $(\mathrm{g})$

IW=Initial weight of extracts $(\mathrm{g})$.

Estimation of total terpenoids

The terpenoid content was estimated using Ferguson's method [37].

\section{Procedure}

$1 \mathrm{~g}$ of the flower powder was taken and soaked in ethanol for $24 \mathrm{~h}$. The extract was filtered, and the filtrate was extracted with petroleum ether using separating funnel. The ether extract was treated as total terpenoids. The obtained residue was dried and weighed. The total terpenoid was calculated using the following formula.

Calculation

Total terpenoid $(\%)=\frac{F W-I W}{S W} \times 100$

Where,

FW=Final weight of petriplate and sample (g)

IW=Initial weight of petriplate $(\mathrm{g})$

$\mathrm{SW}=$ Weight of sample $(\mathrm{g})$.

Estimation of total alkaloids

The estimation of total alkaloids in the flower extract of B. superba was determined using the following method [38] with some modifications.

Reagents

$10 \%$ acetic acid

Ethanol

$\mathrm{NH}_{4} \mathrm{OH}$.

\section{Procedure}

$100 \mathrm{ml}$ of $10 \%$ acetic acid in ethanol was added to $1 \mathrm{~g}$ of dry powdered sample, and then, the extracts were covered and allowed to stand for $4 \mathrm{~h}$. After that, the extracts were filtrated and concentrated on a water bath to $25 \mathrm{ml}$ of its original volume. The droplets of concentrated $\mathrm{NH}_{4} \mathrm{OH}$ were added to the extract until the precipitation of the whole solution to settle, and then, the precipitates were washed with dilute $\mathrm{NH}_{4} \mathrm{OH}$ and then filtered using Whatman filter paper. The residue was dried in the oven at $40^{\circ} \mathrm{C}$ and weighed. The alkaloid content was determined using the following formula:

Calculation

Total alkaloid content $(\%)=\left(\frac{F W}{\mathrm{IW}}\right) \times 10 \mathrm{C}$

Where,

FW=Final weight of sample $(\mathrm{g})$

IW=Initial weight of extracts (g).

\section{RESULTS AND DISCUSSION}

Nature stands a golden mark and provides the storehouse of magic bullet to cure all infirmities of manhood and it has played an active role in providing effective beneficial entities. Plant kingdom represents a rich house of organic compounds. Medicinal plants used in traditional medicine clasp an extensive range of bioactive substances that can be used to treat various diseases [38-41].

In the present study, the inorganic acid radicals are shown in Table 1. 
The inorganic components are obtainable only in trace amounts in plants, which may impact numerous functions. These components are widely used in chemotherapy and are essential in human and animal health [42-44].

In various parts of human body, $\mathrm{pH}$ and acid balance are regulated by the carbonate, as bicarbonate ions [45]. In plants, the prevalence of sulfur is blend in the reduced form [46]. Sulfur is an important element of vitamins, biotin, and coenzyme [47-49]. Chlorides play an important role for regulation of water balance, osmotic pressure, as well as acidbase equilibrium $[47,49]$. Nitrogen is essential for the digestion of food and growth [50]. Fluoride plays an important role to prevent the dental caries in human beings [51]. In plants cells, the basic component is phosphorous, as phosphate ions which maintain blood sugar level, normal heart contraction [52], bone growth, and kidney function when consumed by human beings [53].

Qualitative analysis of basic radicals results is shown in Table 2.

Current report shows that the basic radical such as lead, arsenic, and ferrous was present in the flower extract of B. superba. The role of the inorganic basic radicals in animals and plants is different. Lead is a trace metal which is not essential for either human beings or plants. The impact of lead in plants varies because plants differ in the uptake from soil and sensitivity to lead [54].

In the formation of hemoglobin, iron plays a vital role for normal functioning of the central nervous system $[55,56]$ and transfer of oxygen from the lungs to the tissue [56,57]. Zinc is an essential trace element for plant growth and also plays an important role in various cell processes [58] and also zinc is important for the production of insulin hormone and carbonic anhydrase in the body [59]. Zinc helps in regulating immune function, sperm production, and fetus development [60]. Mercury is a toxic metal, which- is not reported in plants [61]. In carbohydrate, metabolism chromium plays an important role. It also functions in protein and cholesterol synthesis. It is an essential component which is required for the maintenance of normal glucose metabolism. The function of chromium is directly related to the function of insulin, which plays a vital role in diabetes mellitus. Chromium is found in the pancreas, which produces insulin [61].

In the present study, estimation of total saponins, terpenoids, and alkaloids content is shown in the Table. 3. Comparing the percentage of the secondary metabolites of the flower extract of $B$. superba, it was observed in the following order, saponins $<$ terpenoids $<$ alkaloids as 4.18 $1 \pm 0.017 \%<79.833 \pm 0.351 \%<107.823 \pm 0.105 \%$, respectively.

Saponins have antifungal properties $[62,63]$. Saponins are used in hypercholesterolemia, hyperglycemia, antioxidant, anticancer, antiinflammatory, and weight loss $[64,65]$. Saponins give foams in water; it has detergent properties and hemolytic activity [66]. The total saponin content was recorded in the following medicinal plants such as Ocimum sanctum, Mentha spicata, Trigonella foenum graecum, and Spinacia oleracea [67].

Terpenoid compound has been used to treat cancer, malaria, inflammation, and a variety of infectious diseases which are caused by virus and bacteria. The most famous anticancer drug taxol and the antimalarial drug artemisinin are terpene-based drugs [68].

At present, many plant-derived alkaloids are used in clinics, for example, vinblastine and taxol (anticancer agents), morphine and codeine (analgesics), (C)-tubocurarine (muscle relaxant), colchicine (gout suppressant), sanguinarine (antibiotic), and scopolamine (sedative). The important plant origin alkaloids are caffeine, cocaine, nicotine, and the synthetic 0, 0-acetylated morphine derivative heroin [69-71]. Anita and Santosh [72] reported that estimation of chemical compounds from the plant facilitates to produce modern medicines. This study strongly supports the chemical characteristics of the flower of Butea superb which contains many valuable medicinal uses.
Table 1: Analysis of inorganic acid radicals in the flower extract of $B$. superba

\begin{tabular}{lll}
\hline S. No & Acid radicals & Inference \\
\hline 1. & Carbonate & - \\
2. & Chloride & - \\
3. & Chromate & + \\
4. & Nitrate & - \\
5. & Phosphate & + \\
6. & Sulfate & + \\
7. & Sulfide & - \\
\hline Key: (+): Present: (-): Absent. B. superba: Butea superba
\end{tabular}

Table 2: Analysis of inorganic basic radicals in the flower extract of $B$. superba

\begin{tabular}{lll}
\hline S. No & Basic radicals & Inference \\
\hline 1. & Lead & + \\
2. & Arsenic & + \\
3. & Mercury & - \\
4. & Copper & - \\
5. & Ferric & - \\
6. & Ferrous & + \\
7. & Zinc & - \\
8. & Silver & - \\
\hline
\end{tabular}

Key: (+): Present; (-): Absent. B. superba: Butea superba

Table 3: Estimation of total terpenoids, saponins, and alkaloids in the flower extract of $B$. superba

\begin{tabular}{lll}
\hline $\begin{array}{l}\text { S. } \\
\text { No }\end{array}$ & $\begin{array}{l}\text { Secondary } \\
\text { metabolites }\end{array}$ & $\begin{array}{l}\text { \% in } \text { B. superba flower } \\
\text { extract }\end{array}$ \\
\hline 1. & Saponins & $4.181 \pm 0.017$ \\
2. & Terpenoids & $79.833 \pm 0.351$ \\
3. & Alkaloids & $* 107.823 \pm 0.105$ \\
\hline Each value is mean \pm standard deviation of 5 samples expressed as percentage. \\
${ }^{*}$ p $<0.05$ level. (saponins versus terpenoids versus alkaloids). B. superba: Butea \\
superba
\end{tabular}

\section{CONCLUSION}

It can be summarized that the flower was selected for the current study having importance in traditional medicine and it can be considered as a source for the analysis of inorganic elements, estimation of total saponins, terpenoids, and alkaloids. Hence, the present study may be useful for the quality and purity of the plant material in future studies.

\section{ACKNOWLEDGMENT}

None.

\section{AUTHORS' CONTRIBUTION}

All authors contributed equally to this manuscript.

\section{CONFLICTS OF INTEREST}

Identification of bioactive compounds and drug designing.

\section{REFERENCES}

1. Florence AR, Joselin J, Brintha TS, Sukumaran S, Jeeva S. Preliminary phytochemical studies of select members of the family Annonaceae for bioactive constituents. Biosci Discovery 2014;5:85-96.

2. Hammer K, Carson C, Riley T. Antimicrobial activity of essential oils and other plant extracts. J Appl Microbiol 1999;86:985-90.

3. Hassan BA. Medicinal Plants (Importance and Uses). Open Access J Pharmaceut Anal Acta 2012;3:139-41.

4. Anjoo K, Ajay KS. Isolation of stigmasterol and $\beta$-sitosterol from petroleum ether extractog aerial parts of Ageratum conyzoides. Int $\mathrm{J}$ Pharm Pharm Sci 2010;3:94-6. 
5. Somani R, Kasture S, Singhai AK. Antidiabetic potential of Butea monosperma in rats. Fitoterapia 2006;77:86-90.

6. Satyavati GV, Gupta AK, Tandon N. Medicinal plants of India. New Delhi, India: Indian Council of Medical Research; 1987.

7. Sandhya B, Thomas S, Isabel W, Shenbagarathai R. Medicinal plants. Complement Altern Med 2006;3:101-14.

8. Kavitha K. Evaluation of total phenol, total flavonoids, antioxidant and anticancer activity of Mucuna pruriens seed extract. Asian J Pharm 2018;11:242-6.

9. Arzani A, Zeinali H, Razmjo K. Iron and magnesium concentrations of mint accessories (Mentha Spp.). Plant Physiol Biochem 2007;45:323-29.

10. Momin RK, Kadam VB. Determination of ash values of some medicinal plants of genus Sesbania of Marathwada region in Maharashtra. J Phytol 2011;3:52-4.

11. Subramanian R, Gayathri S, Rathnavel C, Raj V. Analysis of mineral and heavy metals in some medicinal plants collected from local market. Asian Pac J Trop Biomed 2012;1:74-8.

12. Tamilarasi L. Antimicrobial and Anthelmintic Efficacy of Aloe vera (Aloe barbadensis Miller, 1768). Ph.D., Thesis, University of Madras, Chennai; 2014.

13. George EB. Treatment of acute lymphocytic leukemia using zinc adjuvant with chemotherapy and radiation: A case history and hypothesis. Med Hypothesis 2005;64:1124-26.

14. Shute KH. The Biological of Trace Elements their Role in Nutrition. Philadelphia, PA, (USA): JB Lippincot Co.; 1964

15. Croteau R, Kutchan TM, Lewis NG, Buchanan B, Gruissem W, Jones $\mathrm{R}$, editors. Natural Products (Secondary Metabolites) in Biochemistry and Molecular Biology of Plants. Vol. 1. Rockville, MD: American Society of Plant Physiologists; 2000. p. 1250-318.

16. Krishnaiah D, Sarbatly R, Bono A. Phytochemical antioxidants for health and medicine. A move towards nature. J Mol Biol Biotechnol 2007;1:97-104.

17. Joshi B, Lekhak S, Sharma A. Antimicrobial property of different medicinal plants: Ocimum sanctum, Cinnamomum zeylanicum, Xanthory lumarmatum and Origanum majorana. Kathmandu Univ J Sci Eng Technol 2009;5:143-50.

18. Zwenger S, Basu C, Plant terpenoids: Applications and potentials. Biotechnol Mol Biol Rev 2008;3:1-7.

19. Dhandapani R, Sabna B. Phytochemical constituents of some Indian medicinal plants. Ancient Sci Life 2008;27:1-8.

20. Hostettmann KM, Hostettmann A, Marston AB, Charlwood V, Banthorpe DV. In: Methods in Plant Biochemistry. Vol. 7. London: Academic Press; 1991. p. 435-71.

21. Konoshima T, Yasuda I, Kashiwada Y, Cosentino LM, Lee KH. Anti-AIDS agents, 21. Triterpenoid saponins as anti-HIV principles from fruits of Gleditsia japonica and Gymnocladus chinensis, and a structure-activity correlation. J Nat Prod 1995;58:1372-7.

22. Mahato SB, Ganguly AN, Sahu NP. Review: Steroid, saponins. Photochemistry 1982;21:959-78.

23. Sen S, Makkar HP, Becker K. Alfalfa saponins and their implication in animal nutrition. J Agric Food Chem 1998;46:131-40.

24. Yongmok K, Hamilton OH, Daniel JW. Determination of saponin and various chemical compounds in Camellia sinensis and Genus Ilex, senses technical (SEN-TN-0027). Fitoterpia 2009;2:387-95.

25. Avato P, Bucci R, Tava A, Vitali C, Rosato A, Bialy Z, et al. Antimicrobial activity of saponins from Medicago sp.: Structure-activity relationship. Phytother Res 2006;20:454-7.

26. Ma YX, Fu HZ, Li M, Sun W, Xu B, Cui JR, et al. An anticancer effect of a new saponin component from Gymnocladus chinensis baillon through inactivation of nuclear factor-kappaB. Anticancer Drugs 2007;18:41-6.

27. Okwu DE, Okwu ME. Chemical composition of Spondia mombin plants. J Sustain Agri Environ 2004;6:140-7.

28. Selvaraj S, Chittibabu CV, Janarthanam B. Studies on phytochemical screening, antioxidant activity and extraction of active compound swertiamarin from leaf extract of Enicostemma littorale. Asian J Pharm clin Res 2014;7:240-4.

29. Sharief N, Srinivasulu A, Rao VU. Estimation of alkaloids and total phenol in roots of Derris trifoliate L and evaluation for antibacterial and antioxidant activity. Indian J Appl Res 2014;4:1-3.

30. Hayashi T, Okanmuka K, Kawasaki M, Morita N. Production of diterpenoids by cultured cells from two scorpariadulas. Phytocochemistry 1993;35:353-6.

31. Stary F. The Natural Guide to Medicinal Herbs and Plants. London: Tiger Books International; 1998. p. 12-6.

32. Cherdshewasart W, Bhuntaku P, Panriansaen R, Dahlan W, Malaivijitnond S. Androgen disruption and toxicity tests of Butea superba Roxb., a traditional herb used for treatment of erectile dysfunction, in male rats. Maturitas 2008;60:131-7.

33. Lu Y, Foo Y. Antioxidant activities of polyphenols from sage (Salvia officinalis). Food Chem 2001;75:197-202.

34. Pizzale L, Bortolomeazzi R, Vichi S, Conte LS. Antioxidant activity of sage and oregano extracts related to their phenolic compound content. J Sci Food Agric 2002;82:1645-51.

35. Khandelwal KR. Practical Pharmacognosy Techniques and Experiments. New Delhi: Niraliprakashan; 2005. p. 15-163.

36. Obadoni BO, Ochuko PO. Phytochemical studies and comparative efficacy of the extracts of some haemostatic plants in Edo and Delta States of Nigeria. Glob J Pure Appl Sci 2001;8:203-8.

37. Ferguson NM. A Text book of Pharmacognosy. New Delhi: MacMilan Company; 1956. p. 191-8.

38. Harborne JB. Phytochemical Methods. A Guide to Modern Techniques of Plant Analysis. $3^{\text {rd }}$ ed. New Delhi: Springer Pvt. Ltd.; 2005.

39. Balakumar S, Rajan S, Thirunalasundari T, Jeeva S. Antifungal activity of Aegle marmelos (L.) Correa (Rutaceae) leaf extract on dermatophytes. Asian Pac J Trop Biomed 2011;1:309-12.

40. Rajan S, Thirunalasundari T, Jeeva S. Anti-enteric bacterial activity and phytochemical analysis of the seed kernel extract of Mangifera indica Linnaeus against Shigell adysenteriae (Shiga, corrig.) Castellani and Chalmers. Asian Pac J Trop Biomed 2011;4:294-300.

41. Florence AR, Joselin J, Jeeva S. Intra-specific variation of bioactive principles in select members of the genus Clerodendrum L. J Chem Pharm Res 2012;4:4908-14.

42. Khan IZ. The Role of Chemistry in Health, Disease and Aging. Maiduguri: A Seminar Paper Presented in the Department of Chemistry, University of Maiduguri; 1996.

43. Ogugbuaja VO, Akinniyi JA, Abdulrahman FI, Ogarawu VC. Elemental Contents of Medicinal Plants. A Monograph. Nigeria: Department of Chemistry, Faculty of Science, University of Maiduguri; 1997.

44. Joselin J, Brintha TS, Florence AR, Jeeva S. Screening of select ornamental flowers of the family Apocynaceae for phytochemical constituents. Asian Pac J Trop Dis 2012;2:260-4.

45. Moses EA, Ogugbuaja VO, Ogarawu VC. Enrichment of element of Nigerian bituminous coal fly ash and their effects on hematological parameters of exposed rabbits. Nig J Exp Appl Biol 2002;3:95-100.

46. Wattoo FH, Tirmizi SA, Wattoo MH, Anjum A, Iqbal J, Ghanghro AB, et al. Analytical investigation of selected inorganic nutrients of desert growing Aloes. J Chem Soc Pak 2008;30:394-9.

47. Herry JB, Statland BE. Chemical Pathalogy and Clinical Chemistry. Philadelphia, PA: W.B. Saunders Company; 1979.

48. Bick JA, Leustek T. Plant sulphur metabolism-the reduction of sulphate to sulphite. Curr Opin Plant Biol 1998;1:240-4.

49. Chouhan F, Wattoo MH, Tirmizi SA, Menon FZ, Rahman A, Tufail M. Analytical investigation of inorganic nutritive elements of Capparis decidua grown in Cholistan desert. Nucleus 2002;39:195-9.

50. Tirmizi SA, Wattoo FH, Wattoo MH, Kanwal S, Iqbal J. Inorganic nutrients of Saccharum bengalense. Chem Soc Pak 2005;27:186-9.

51. Cooper J. Structure and biological activity of nitrogen and oxygen; Coordinated nicotinic acid complexes of chromium. Inorg Chem 1984;91:1-9.

52. Richard GF. Inorganic fluorides Canadian environmental protection act. Fluoride 1995;28:29-32

53. Manria CL. Nutritional Biochemistry and Metabolism with Clinical Applications. Vol. 2. Norwalk: Appleton and Lange; 1991. p. 191-212.

54. Johns T, Duquette M. Deficiency of phosphorus in man. Am J Clin Nutr 1991;53:448-56.

55. Demayo A, Taylor MC, Taylor KW, Hodson PV. Toxic effects of lead and lead compounds on human health, aquatic life, wildlife plants, and livestock. CRC Crit Rev Environ Control 1982;12:257-305.

56. Otsuki N, Dang NH, Kumagai E, Kondo A, Iwata S, Morimoto C. Aqueous extract of Carica papaya leaves exhibit anti-tumor activity and immunomodulatory effects. J Ethnopharmacol 2010;127:760-7.

57. Adesuyi AO, Awosanya OA, Adaramola FB, Omeonu AI. Nutritional and phytochemical screening of $A$. barbedensis. Curr Res J Biol Sci 2011;4:4-9.

58. Sigel H. Metals in Biological Systems. New York, USA: Marcel Dekker; 1978.

59. Hunt JR. Bioavailability of iron, zinc, and other trace minerals from vegetarian diets. Am J Clin Nutr 2008;78:633-9.

60. Kavitha K, Jayanthi J, Ragunathan MG. Physico chemical parameters, phytochemical analysis, acid and basic radicals analysis in the leaf extract of Hybanthus enneaspermus (L.). F. Muell. Int J Curr Adv Res 2017;6:7634-9.

61. Okwu DE. Phytochemicals and vitamin content of indigenous spices of south eastern Nigeria. J Sustain Agric Environ 2004;6:30-4 
62. Zetic VG, Tomas VS, Grba S, Lutilsky L, Kozlek D. Chromium uptake by Saccharomyces cerevisiae and isolation of glucose tolerance factor from yeast biomass. J Biosci 2001;26:217-23.

63. Karumari RJ. Studies on the Efficacy of Ocimum sanctum (Linnaeus, 1767) and its Antifertility Effect with Reference to Male Rattusnor vegicus (Berkenhout, 1769). Ph.D., Thesis, University of Madras, Chennai; 2013.

64. Aboada OO, Efuwape BM. Antibacterial properties of some Nigerian species. Biol Res Comm 2001;13:183-8.

65. Mohanta TK, Patra JK, Rath SK, Pal DK, Thatoi HN. Evaluation of antimicrobial activity and phytochemical screening of oils and nuts of Semicarpusana cardium (L). Sci Res Essay 2007;2:486-90.

66. Mandal P, SinhaBabu SP, Mandal NC. Antimicrobial activity of saponins from Acacia auriculiformis. Fitoterapia 2005;76:462-5.
67. Manjunatha BK. Antibacterial activity of Pterocarpu santalinus. Ind J Pharm Sci 2006;68:115-6.

68. Sezgin AE, Artik N. Determination of saponin content in Turkish tahini halvah by using HPLC. Adv J Food Sci Technol 2010;2:109-15.

69. Facchini PJ. Annual revised plant physiology. Plant Mol Biol 2001;52:29-66.

70. Guangyi W, Weiping T, Bidigare RR. Terpenoids as therapeutic drugs and pharmaceutical agents. Nat Prod 2005;2:197-227.

71. Anjali S, Sheetal S. Phytochemical analysis and free radical scavenging potential of herbal and medicinal plant extracts. J Pharm Phytochem 2013;2:22-9

72. Anita SW, Santosh RB. Plant profile, phytochemistry and pharmacology of Spathodea campanulata P. Beauvais (African tulip tree): A review. Indian J Pharm Pharm Sci 2018;10:1-6. 